\title{
Affect of Process Electrokinetics Against Minerals and Molecules of Expansive Clay
}

\author{
Nahesson Hotmarama Panjaitan ${ }^{1}$, Ahmad Rifa' $^{2}$, Agus Darmawan Adi $^{2}$, \\ P. Sumardi ${ }^{3}$ \\ ${ }^{I}$ Doctoral Candidate, Department of Civil and Environmental Engineering Faculty of Engineering, Gadjah \\ Mada University, Indonesia and Lecturer of Department of Civil Engineering State University of Medan, \\ Indonesia, \\ ${ }^{2}$ Associate Professor Department of Civil and Environmental Engineering, Gadjah Mada University, Indonesia \\ ${ }^{3}$ Associate Professor Department of Chemistry Engineering, Gadjah Mada University, Indonesia.
}

\begin{abstract}
This journal is a series of research expansive clay stabilization with lime and using electrokinetics process. Some research results have been achieved in this study such of phenomena of electrophoresis, phenomena of electrochemical, phenomena of electroosmosis, and behaviors spread of lime on clay particles using electrokinetics process, has been published on the topic of another discussion. The method of research is an experimental study using an open box made of glass, and the use of electricity (DC) with a capacity of $25 \mathrm{~V}$, 2A. The research using 2 types of expansive clay soil, taken from the region of Central Java. The results of this paper discusses research on the influence of electrokinetics process on expansive clay minerals, so that the results achieved in this research can be used for the development of electrokinetics process as an alternative to the process of stabilization of expansive clay. Behavioral changes of kind of minerals and morphology molecular of clay identified by using XRD and testing SEM. The test results on the types of minerals clay by $\mathrm{XRD}$, indicating that electrokinetics process does not result in changes in the types of clay minerals. SEM testing in clay soils, showed that the results of the deployment of lime solution using electrokinetics process, succeeded in putting lime attach to molecules of clay. The results of this study indicate that the electrokinetics potential to be developed as an alternative to expansive clay stabilization.
\end{abstract}

Keywords: Electrokinetics process, expansive clay, stabilization, lime, cation exchange.

\section{INTRODUCTION}

Research on expansive clay, show that behavior of swell and shrink expansive clay, influenced by molecule of clay and also the presence of cations that is able to bind water relatively more than other cations. Expansive clay stabilization using a stabilizer material such as lime, aims to replace the cations that potentially bind more water with another cations that more stable (in this case the ability to bind less water). Cation exchange can occur due to a change in the equilibrium electric charge on the clay surface caused by electrokinetics process. This study was conducted to see the affect of electrokinetic process using lime solution to changes in the type of mineral and molecular morphology of expansive clay.

\section{LITERATURE REVIEW}

\subsection{Minerals of Clay}

The results of the research that has been conducted on the mineral composition of rocks, soils and sediments in the earth indicate that the most common element in nature after oxygen are elements silicone $(\mathrm{Si})$ and aluminum ( $\mathrm{Al}$ ) (Table 1.). So it is understandable that most of the molecules of rock and soil (including clay) prepared by silica $\left(\mathrm{SiO}_{2}\right)$ and alumina $\left(\mathrm{Al}_{2} \mathrm{O}_{3}\right)$. At clay molecule ratio of silica and alumina can formed by ratio 1:1 or 2:1 (Fig.1). Because chemical processes, physical processes and mechanical processes in nature, clay particles had changes the balance of electric charge on the surface. The results of research showed that the result of these processes causes surface of clay becomes the negatively charged. To form a stable molecular bond, clay requires positive ions (cations) which are freely located nearby.

The behavior of some cations found in clay minerals to the water binding capability can be seen in Table 2. Results showed that the cations sodium $\left(\mathrm{Na}^{+}\right)$has the ability to bind more water than others, so the presence of these ions causes clay soil to swell and shrinkage behavior very large and expansive clays called. In addition, the results of research of the clay molecule also showed that the montmorillonite type have potential behaviour of swell and shrinkage is greater than the other minerals. It can be concluded that expansive clays is the type of clay that has potential swell and shrinkage very large caused by the molecular structure of the clay of 
his own and also the presence of certain types of cations $\left(\mathrm{Na}^{+}\right.$ions) that have the potential bind water relatively more than other cations.

1:1 Clay

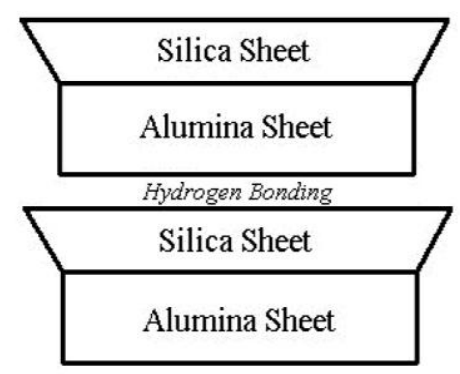

(a)
2:1 Clay

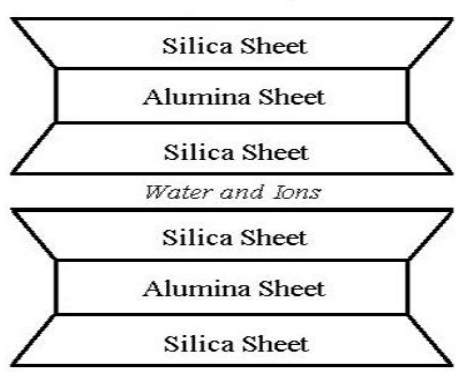

(b)

Fig. 1. Comparison composition of silica : alumina on sheet of the constituent of clay soil (a) composition of (1:1) and (b) composition of 2:1 [1]

Table 1. Composition minerals on soils, core and sediment soils [2]

\begin{tabular}{|c|c|c|c|c|}
\hline \multirow{2}{*}{ Element } & \multicolumn{2}{|c|}{ Soil (mg/kg) } & \multirow{2}{*}{ Core (mean) } & \multirow{2}{*}{ Sediment (mean) } \\
\hline & Median & Range & & \\
\hline $\mathbf{O}$ & 490.000 & - & 474.000 & 486.000 \\
\hline $\mathbf{S i}$ & 330.000 & $250.000-410.000$ & 277.000 & 245.000 \\
\hline Al & 71.000 & $10000-300.000$ & 82.000 & 72.000 \\
\hline $\mathbf{F e}$ & 40.000 & $2.000-550.000$ & 41.000 & 41.000 \\
\hline $\mathrm{C}$ (total) & 20.000 & $7.000-500.000$ & 480 & 29.400 \\
\hline $\mathbf{C a}$ & 15.000 & $700-500.000$ & 41.000 & 66.000 \\
\hline Mg & 5.000 & $400-9.000$ & 23.000 & 14.000 \\
\hline $\mathbf{K}$ & 14.000 & $80-37.000$ & 21.000 & 20.000 \\
\hline $\mathbf{N a}$ & 5.000 & $150-25.000$ & 23.000 & 5.700 \\
\hline Mn & 1.000 & $20-10.000$ & 950 & 770 \\
\hline $\mathbf{Z n}$ & 90 & $1-900$ & 75 & 95 \\
\hline Mo & 1,2 & $0.1-40$ & 1,5 & 2 \\
\hline $\mathbf{N i}$ & 50 & $2-750$ & 80 & 52 \\
\hline $\mathbf{C u}$ & 30 & $2-250$ & 50 & 33 \\
\hline $\mathbf{N}$ & 2.000 & $200-5.000$ & 25 & 470 \\
\hline $\mathbf{P}$ & 800 & $35-5.300$ & 1.000 & 670 \\
\hline$S$ (total) & 700 & $30-1.600$ & 260 & 2.200 \\
\hline
\end{tabular}


Table 2. Correlation of Cations with Atterberg Limit Value (Liquid, Plastic and Shrinkage Limits) [3]

\begin{tabular}{|c|c|c|c|c|c|}
\hline Mineral & $\begin{array}{c}\text { Exchangeable } \\
\text { Ion }\end{array}$ & $\begin{array}{c}\text { Liquid } \\
\text { Limit } \\
\text { ( \%) }\end{array}$ & $\begin{array}{c}\text { Plastic } \\
\text { Limit (\%) }\end{array}$ & $\begin{array}{l}\text { Plasticity } \\
\text { Index }\end{array}$ & $\begin{array}{l}\text { Shrinkage } \\
\text { Limit ( \%) }\end{array}$ \\
\hline Montmorillonite & $\mathrm{Na}$ & 710 & 54 & 656 & 9.9 \\
\hline \multirow[t]{5}{*}{$(\mathrm{OH})_{4} \mathrm{Si}_{8} \mathrm{Al}_{4} \mathrm{O}_{20} \cdot \mathrm{nH}_{2} \mathrm{O}$} & $\mathrm{K}$ & 660 & 98 & 562 & 9.3 \\
\hline & $\mathrm{Ca}$ & 510 & 81 & 429 & 10.5 \\
\hline & $\mathrm{Mg}$ & 410 & 60 & 350 & 14.7 \\
\hline & $\mathrm{Fe}$ & 290 & 75 & 215 & 10.3 \\
\hline & $\mathrm{Fe}^{\mathrm{a}}$ & 140 & 73 & 67 & -- \\
\hline Illite & $\mathrm{Na}$ & 120 & 53 & 67 & 15.4 \\
\hline$\left(\mathrm{KH}_{2} \mathbf{O}\right)_{2}(\mathrm{Si})_{8}$ & $\mathrm{~K}$ & 120 & 60 & 60 & 17.5 \\
\hline$(\mathrm{AlMgFe})_{4,6}$ & $\mathrm{Ca}$ & 100 & 45 & 55 & 16.8 \\
\hline \multirow{3}{*}{$\mathrm{O}_{20}(\mathrm{OH})_{4}$} & $\mathrm{Mg}$ & 95 & 46 & 49 & 14.7 \\
\hline & $\mathrm{Fe}$ & 110 & 49 & 61 & 15.3 \\
\hline & $\mathrm{Fe}^{\mathrm{a}}$ & 79 & 46 & 33 & --- \\
\hline Kaolite & $\mathrm{Na}$ & 53 & 32 & 21 & 26.8 \\
\hline$(\mathrm{OH})_{8} \mathrm{Si}_{4}$ & $\mathrm{~K}$ & 49 & 29 & 20 & --- \\
\hline \multirow[t]{4}{*}{$\mathbf{A l}_{4} \mathbf{O}_{10}$} & $\mathrm{Ca}$ & 38 & 27 & 11 & 24.5 \\
\hline & $\mathrm{Mg}$ & 54 & 31 & 23 & 28.7 \\
\hline & $\mathrm{Fe}$ & 59 & 37 & 22 & 29.2 \\
\hline & $\mathrm{Fe}^{\mathrm{a}}$ & 56 & 35 & 21 & --. \\
\hline
\end{tabular}

\subsection{Electrokinetics Process}

Simple concept of electrokinetics process is 2 pieces of electrodes mounted on the media, then given an electric potential difference. Since the potential difference causes electrons from the cathode (negative pole) moves to the anode (positive pole) [4]. Electrokinetics process can occur if there is fluid in the clay medium that serves as a liaison between the anode and cathode.

The movement of electrons which causes an electric field on the clay, causing the movement of other anions and cations in the soil [1]. Due to the movement of electrons during the electrokinetics process, bonding of cations with clay particles could be disconnected. Phenomenon disconnec of cations bonding with the clay particles are affected by the action and reaction force between electric field and the cation electronegativity. If the electric field strength is greater than the electronegativity of cations, cation bonding with the clay particles will be disconnected. Cation regardless of the clay particles will move towards the cathode. This phenomenon is referred electromigration (Fig.3.).

Excess electric charge (negative charge) on the surface of clay particles, potentially causing clay particles attract cations that are around to form a new balance of electric charge on the particle surface, and this phenomenon is called cation exchange. Overall, this research also observed the phenomenon of cation exchange on clay particles. Cation exchange performed by using cations $\mathrm{Ca}^{2+}$ from lime solution.

In addition to electromigration, during electrokinetics process also occurs electrochemical, electroosmosis and electrophoresis (Fig.2.). Electrochemical processes that occur during the electrokinetics process, produce cations and anions in the electrolyte. If electrolyte using water, a chemical reaction will occur as follows:

$$
\begin{aligned}
& \text { Anode : } 2 \mathrm{H}_{2} \mathrm{O} \rightarrow 4 \mathrm{H}^{+}+\mathrm{O}_{2} \\
& \text { Cathode : } 2 \mathrm{H}_{2} \mathrm{O} \rightarrow 2(\mathrm{OH})^{-}+\mathrm{H}_{2}
\end{aligned}
$$

If the solution in the anode is lime and in the cathode is distilled water, then the chemical reaction that occurs are:

$$
\begin{array}{ll}
\text { Anode } & : \mathrm{Ca}(\mathrm{OH})_{2} \rightarrow \mathrm{Ca}^{2+}+2 \mathrm{H}^{+}+\mathrm{O}_{2} \\
\text { Cathode } & : 2 \mathrm{H}_{2} \mathrm{O} \rightarrow 2(\mathrm{OH})^{-}+\mathrm{H}_{2}
\end{array}
$$

Testing chemicals on clay particles in electrokinetics process using lime, obtained results an increase in the concentration of $\mathrm{Ca}^{2+}$ ions in the soil particles at a specific time period (Fig. 4.). Results as in Fig. 3. and Fig. 4. show that the phenomena of electrochemical, phenomena of electromigration and cation exchange occurs during elecrokinetics process. 


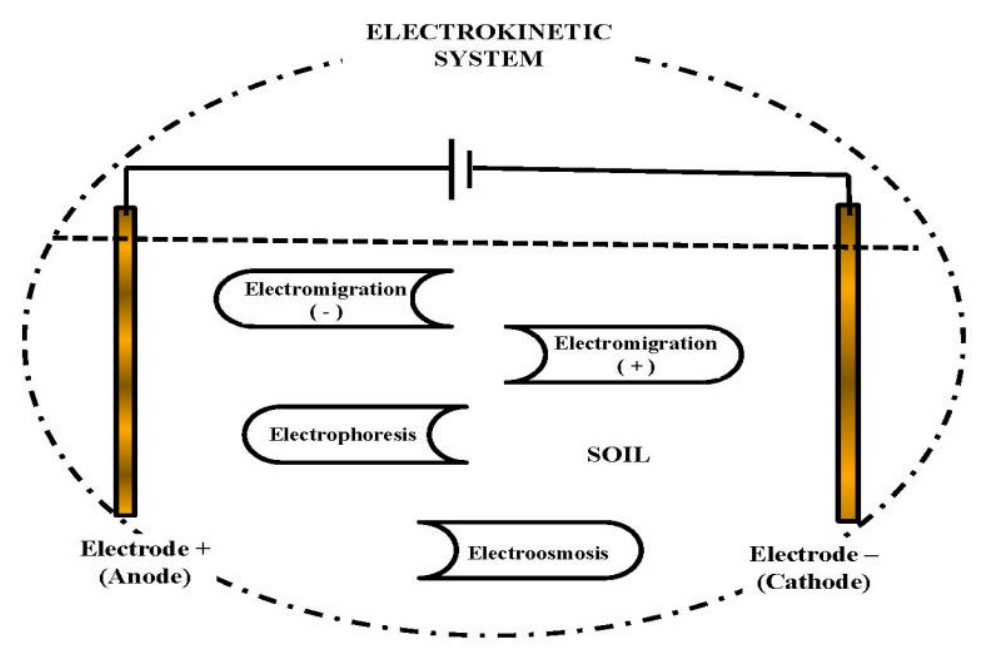

Fig. 2. Illustration phenomenon of electrophoresis, electromigration and electroosmosis during electrokinetics process

\section{SCOPE AND LIMITATIONS}

The scope of this research is limited only to find out the influence of the movement of electricity due to the process of electrokinetics to changes in the minerals of expansive clay. Tests on clay minerals carried by the XRD method, by comparing the original clay minerals with minerals of clay after electrokinetics. XRD results were then compared with observations morphology of clay molecules by using SEM (Scanning Elecron Microscopy).

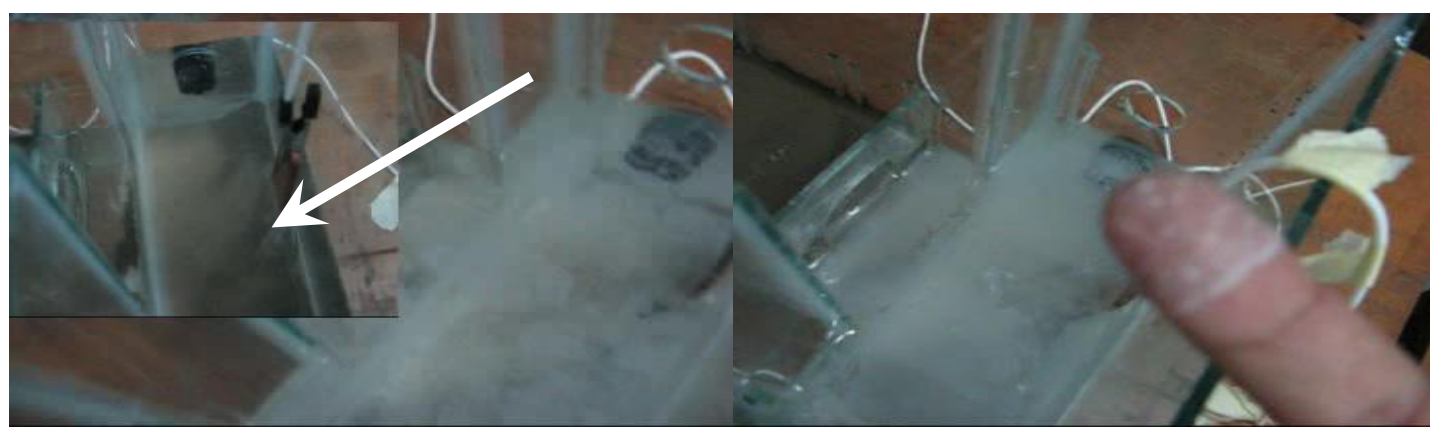

( a )

( b )

Fig. 3. Visual observation of phenomenon caused electrokinetics process on clay sample (a). condition at cathode chamber (upper left corner of the image is before electrokinetics) (b). traces of lime on the finger [6]

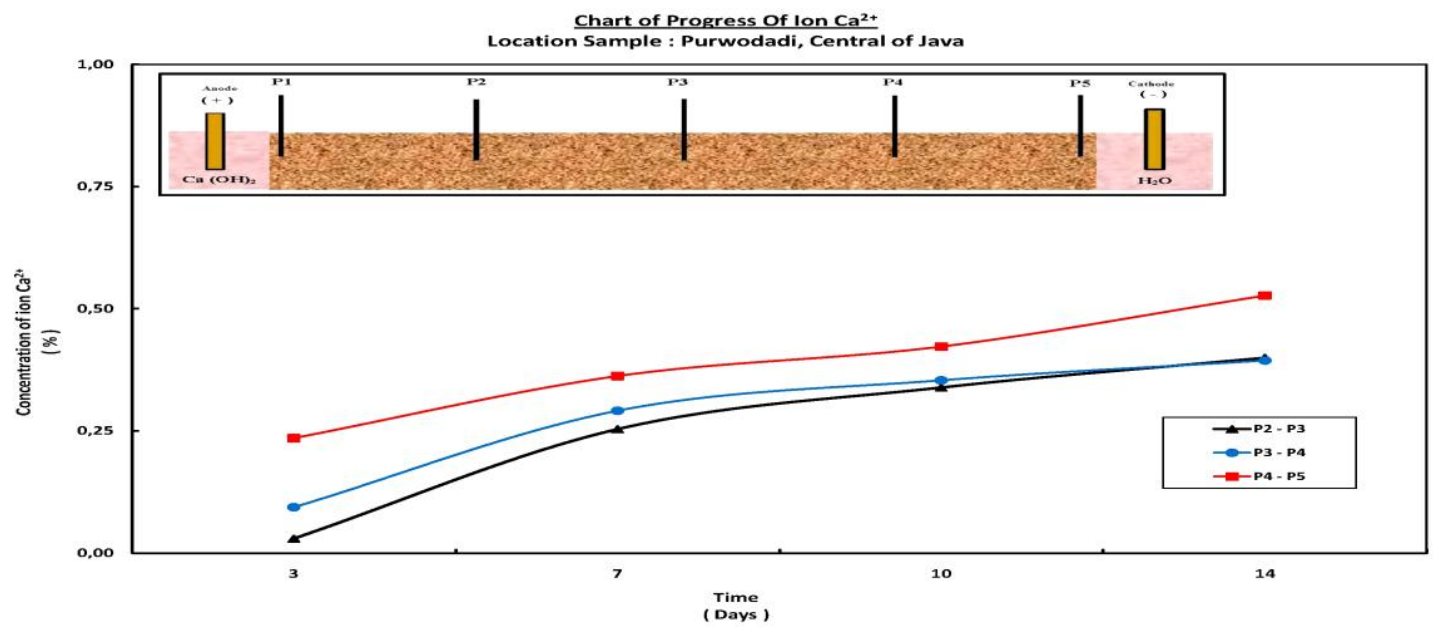

Fig. 4. Progress of ion $\mathrm{Ca}^{2+}$ on clay particles during electrokinetics process [7] 


\section{METHODS AND MATERIALS}

This research was conducted with method of experimental research with use two kinds of expansive clay from Central Java region (Boyolali and Klaten). Disturbed sample of expansive clay was taken at a depth $+/-50 \mathrm{~cm}$. Media testing used on research was glass box, where schematic of testing can be seen in Fig. 5. All of electrode used in this research made of copper material. Electrolytic solutions that use is aquades and a solution of lime. Process of electrokinetics that was done on this reasearch using an electric current direct (DC) with the capacity of 25 Volt and 2A. Electrokinetics system that used in this study is by placing main electrodes are connected to the main power supply, and additional electrodes were placed along the clay sample with a certain distance and connected with AVO meter.

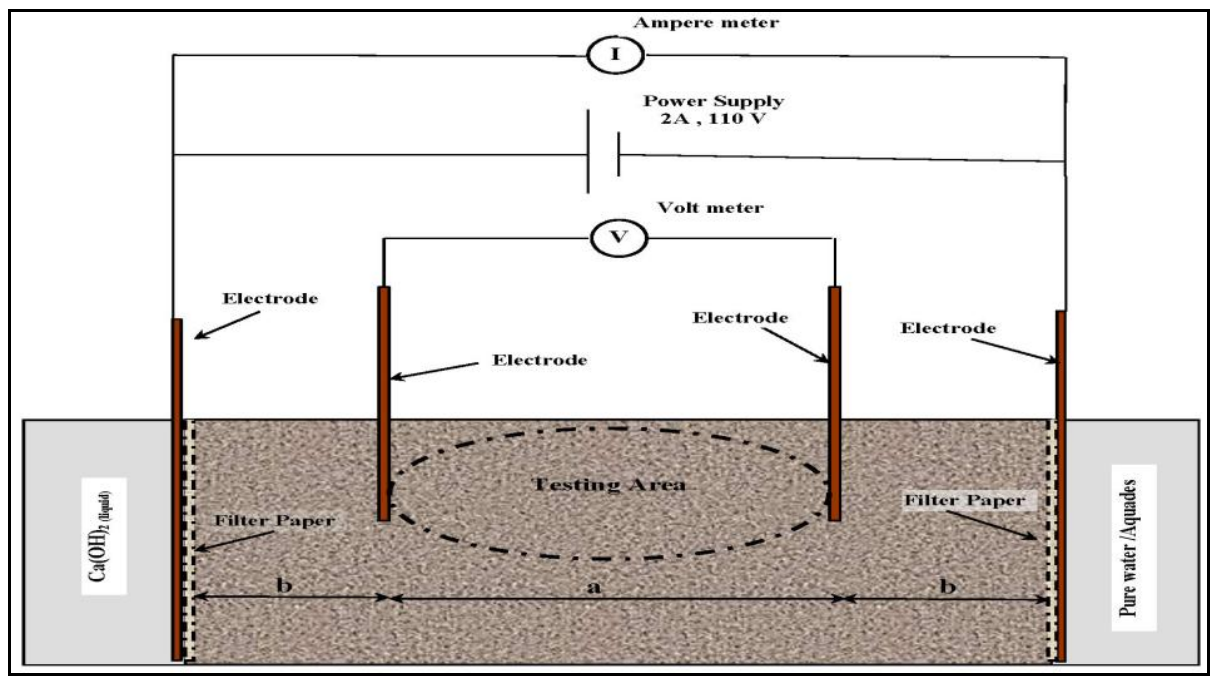

Figure 5. Schematic of testing of electrokinetics process on expansive clay [7]

Testing limits Atterberg conducted to determine physical properties of clay. Chemical testing clay carried by AAS method (Atomic Absorption Spectrometer) to determine the type of clay. Clay mineral testing done at the beginning and end of the electrokinetics process by using XRD and SEM. Electrokinetics process carried out for 21 days. Samples for XRD and SEM tests taken at the end of the electrokinetics process.

\section{RESULT AND DISCUSSION}

In this research, chemical testing performed on clay minerals before electrokinetics process, then the results were compared with physical properties of clay.

\subsection{Chemical and properties testing of clay}

Results of testing chemical and physical properties for clay can be seen on Table 3. below.

Table 3. Index properties and minerals composition of expansive clay of Boyolali and Klaten

\section{Locations}

\section{Items}

\begin{tabular}{lcc} 
& Boyolali & Klaten \\
\hline \hline Atterberg Limits & & \\
$\mathrm{LL}(\%)$ & 74,73 & 73,16 \\
$\mathrm{PL}(\%)$ & 20.95 & 22,18 \\
$\mathrm{PI}(\%)$ & 53,78 & 50,98 \\
$\mathrm{SL}$ & 6,94 & 7,56 \\
\hline \hline Formation of Minerals ( \% ) & & \\
$\mathrm{Al}_{2} \mathrm{O}_{3}$ & 19,69 & 20,20 \\
$\mathrm{SiO}_{2}$ & 56,24 & 62,41 \\
$\mathrm{CaO}$ & 2,72 & 3,19 \\
$\mathrm{Fe} \mathrm{O}_{3}$ & 16,76 & 8,72 \\
$\mathrm{MgO}$ & 0,70 & 1,50 \\
$\mathrm{~K}_{2} \mathrm{O}$ & 0,22 & 0,45 \\
$\mathrm{Na}_{2} \mathrm{O}$ & 0,89 & 1,33 \\
\hline \hline
\end{tabular}


From the results testing chemical of minerals and also atterberg limits of clay, indicates that clay used in this research is type of expansive clay. This conclusion based against combination comparison molecules silica and alumina reach greater than comparison 2: 1 . The presence of sodium ions $\left(\mathrm{Na}^{+}\right)$with a total of $0.89 \%$ $1.33 \%$ also indicates that the type of clay that used in this research is expansive clay. Atterberg limits test results also showed that the samples used in this study is a kind of expansive clay. It can be seen from the value of the Liquid Limit (LL) > 60 [8], Plasticity Index (PI) > 35, and Shrinkage Limit (SL) < 11 [9].

\subsection{Minerals testing of clay}

Testing minerals and morphology of clay done with XRD and SEM. The result of testing XRD can be seen in Fig. 6. and Fig. 7. following.

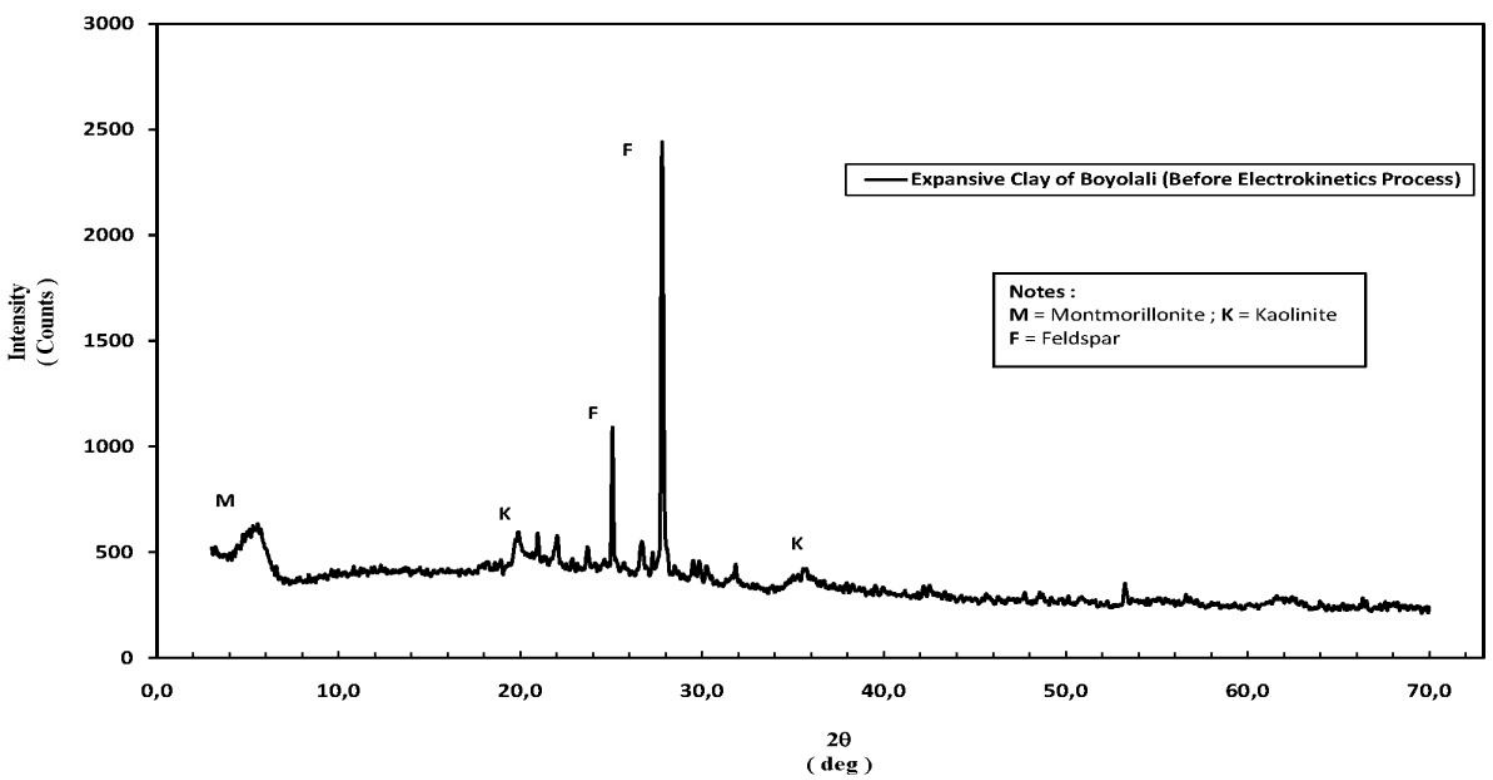

( a )

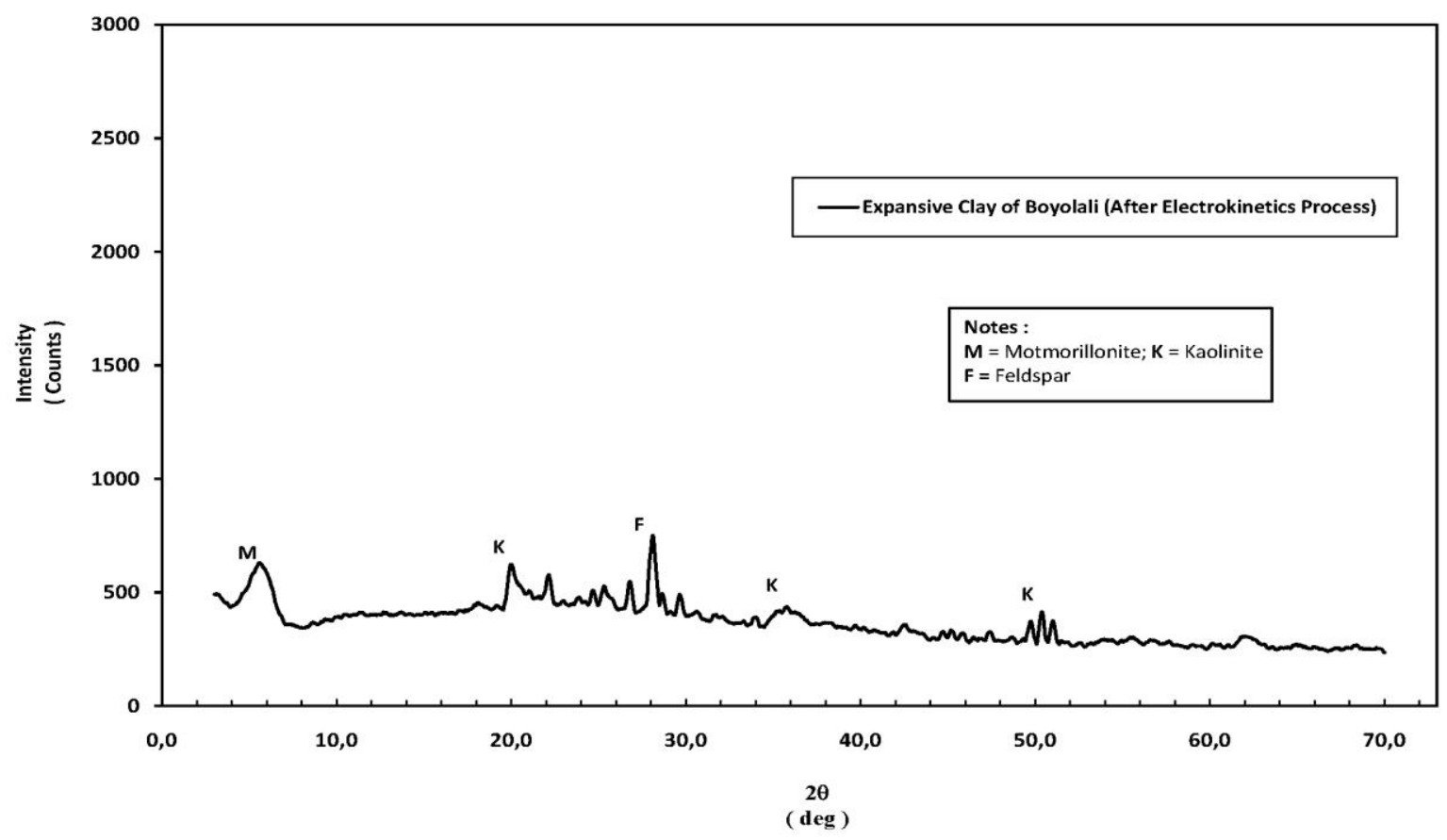

( b )

Figure 6. X-Ray Diffractometer chart for expansive clay of Boyolali, (a). before electrokinetics process, (b), after electrokinetics process. 


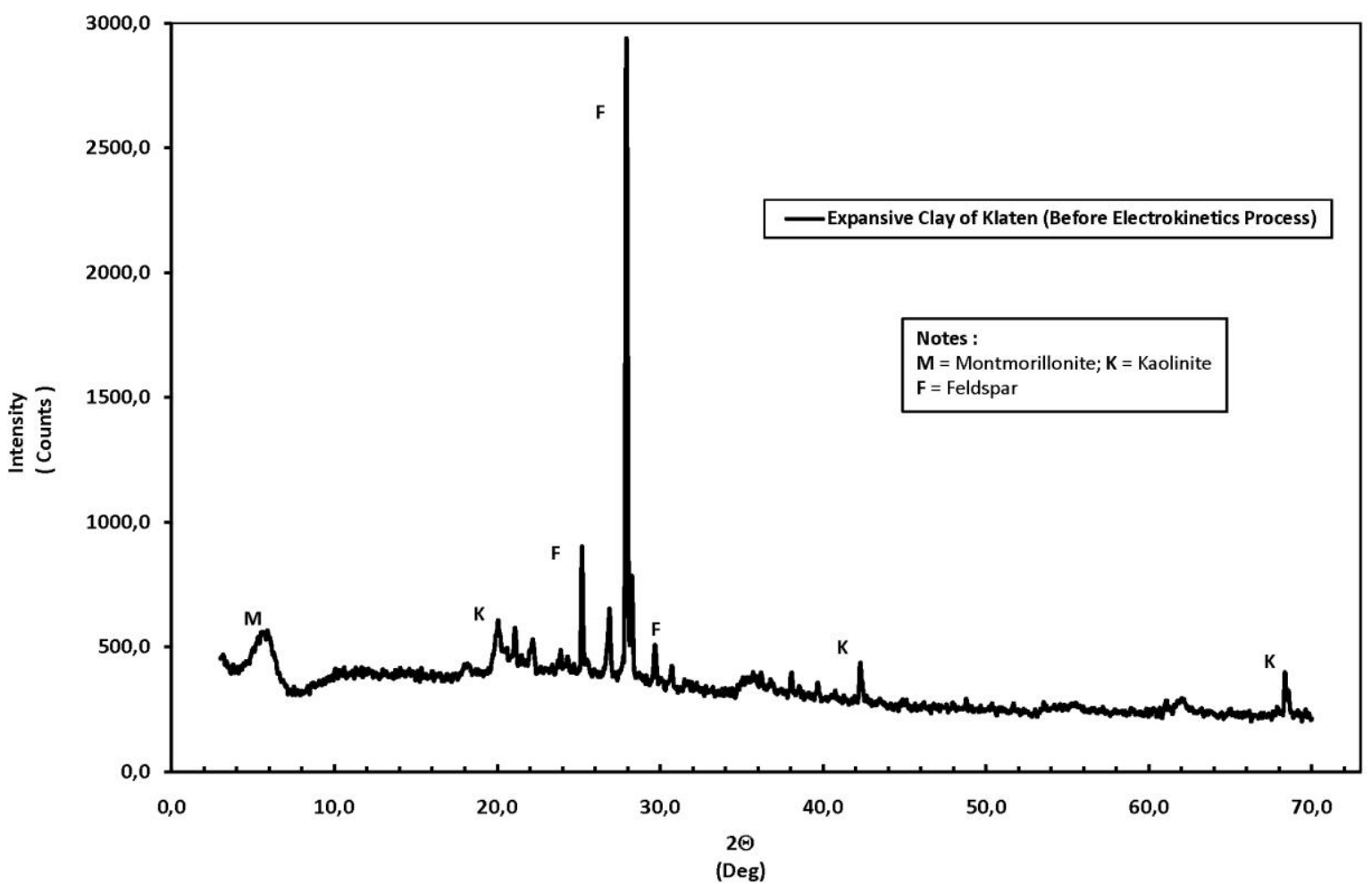

( a )

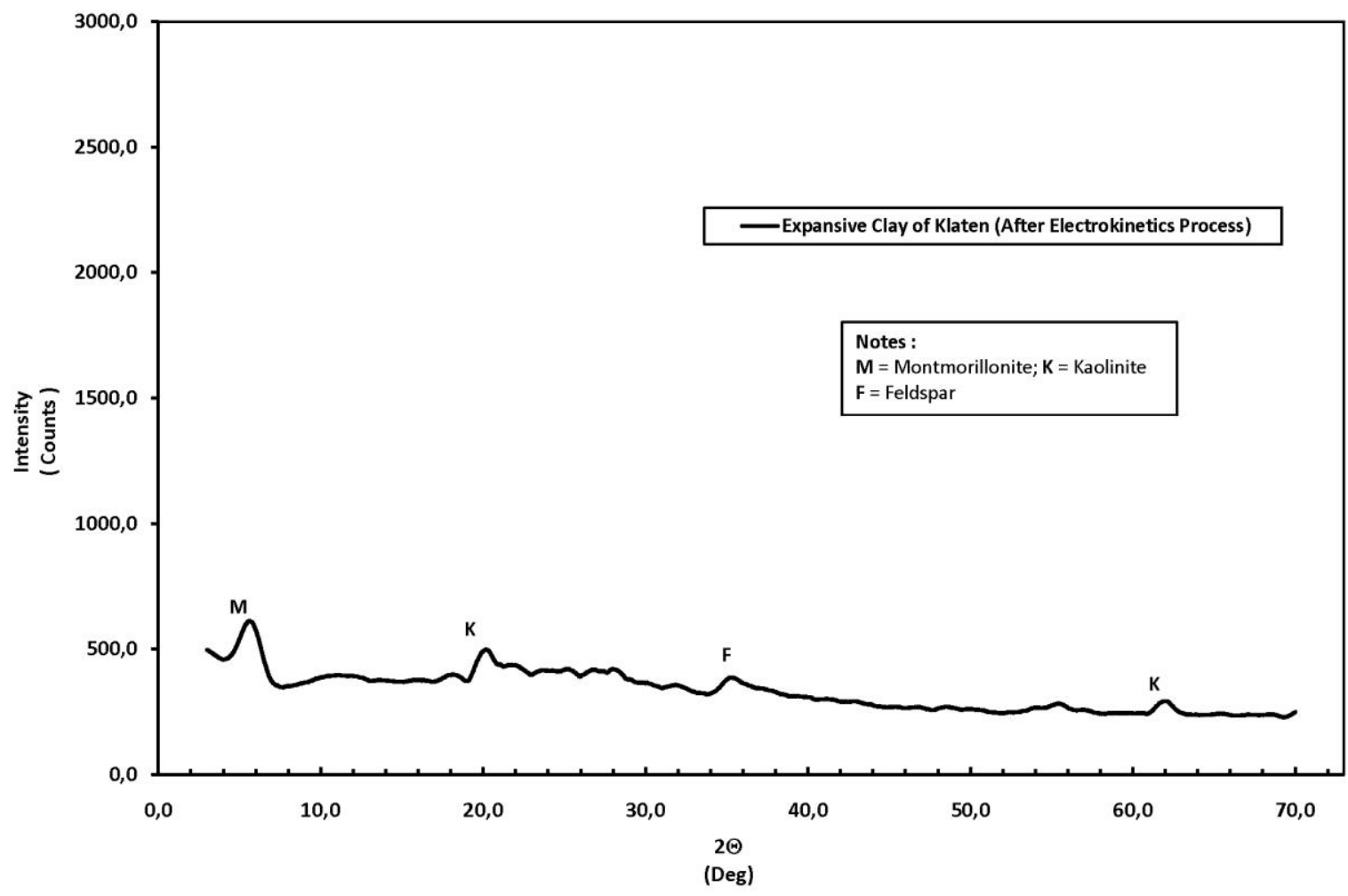

(b)

Figure 7. X-Ray Diffractometer chart for expansive clay of Klaten, (a). before electrokinetics process, (b), after electrokinetics process.

XRD test results of expansive clay minerals before electronic processes in both clay (Boyolali and Klaten) (Fig. 6.(a). and Fig. 7.(a). are Montmorillonite (M), Kaolinite (K) and Feldspar (F). After electrokinetics 
process, minerals of clay also same as before electrokinetic process (Fig. 6. (b). and Fig. 7.(b)). That result show that electrokinetic does not change types of minerals of clay.

Observations morphology molecules of clay by using SEM can be seen in Fig. 8. below. The results of observations can be used to compare morphology the clay molecules before and after the process of electrokinetics. Observation by SEM showed the results of white traces on the clay molecules after electrokinetics process ( Fig. 8. (1b) and (2b) ).

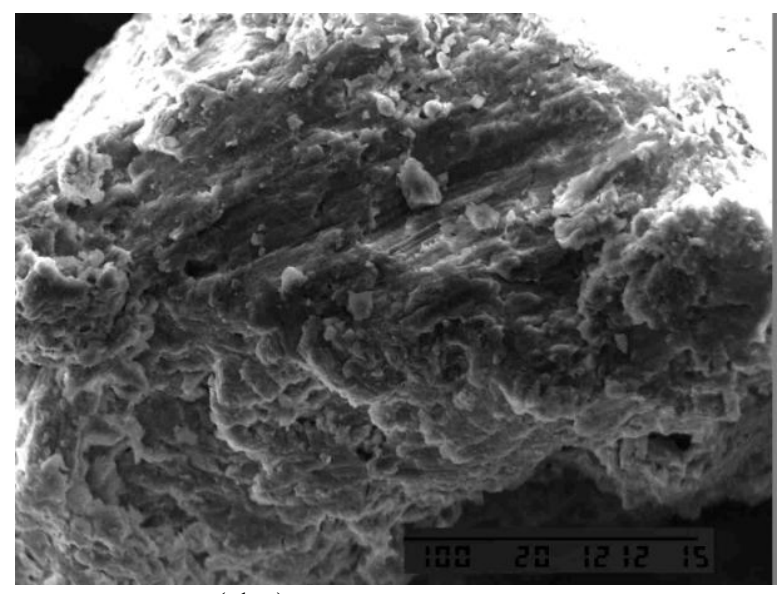

( 1a )

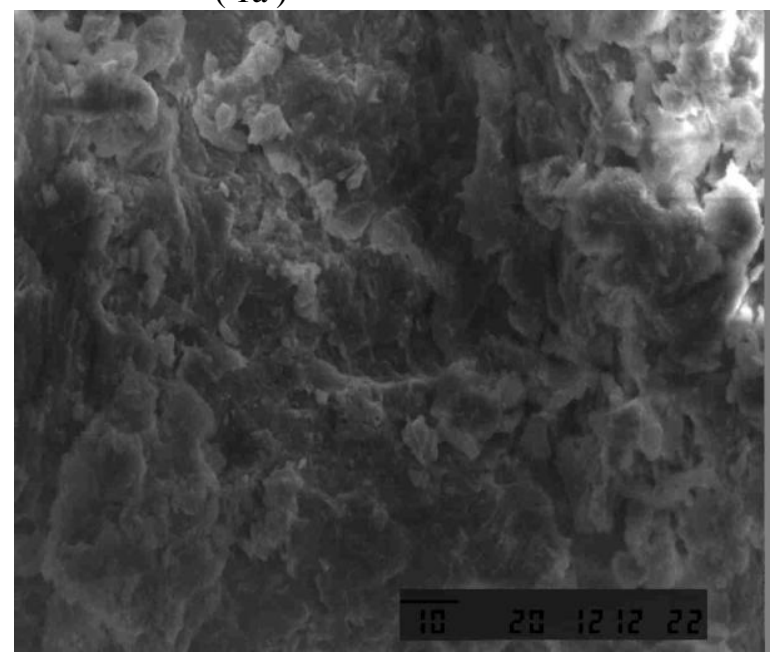

( $2 \mathrm{a})$

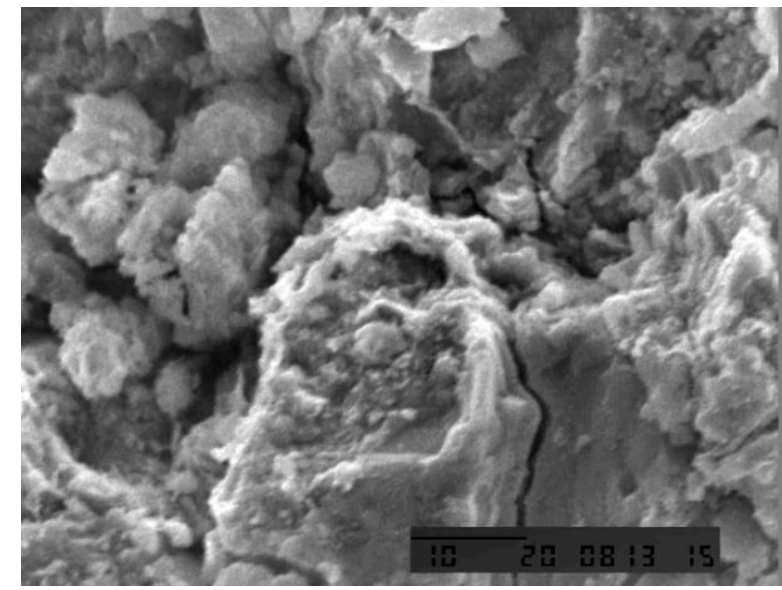

( $1 \mathrm{~b})$

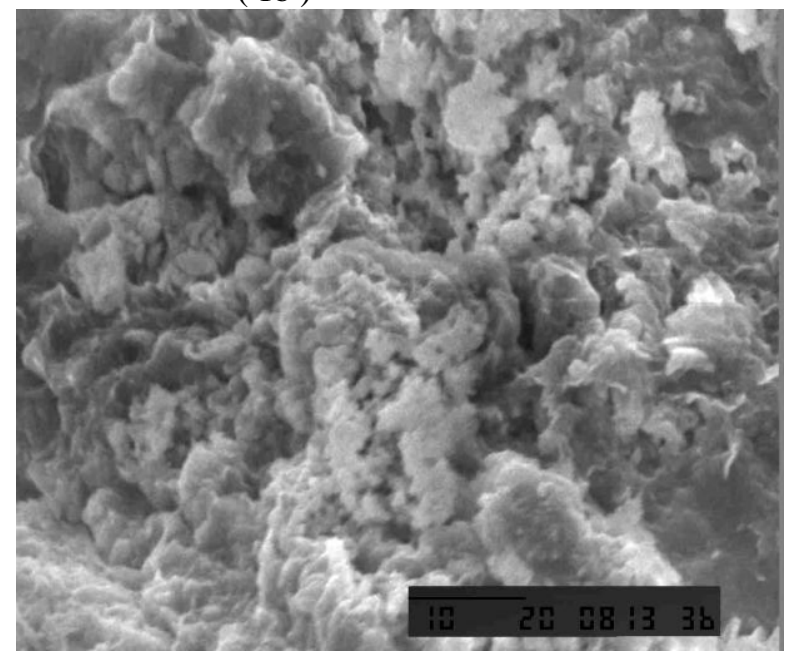

( $2 \mathrm{~b})$

Figure 8. Morphology of molecules of clay for (1). expansive clay of Boyolali, (2). expansive clay of Klaten, (a). before electrokinetics process, (b). after electrokinetics process

\section{CONCLUSION}

From the results of tests performed in this research, it can be concluded that the electrokinetics process does not change types of minerals and morphology of molecules of clay. Test results with SEM, show the presence of traces of lime on expansive clay minerals. This phenomenon is called the physicochemical. The results of these tests combined with testing physical and mechanical properties of clay can be as a reference for the development of electrokinetics process as an alternative stabilization of expansive clay.

\section{ACKNOWLEDGEMENTS}

This research funded by the Indonesian government c/q Directorate General of higher education (DIKTI) through the program of Grant of Disertation Doctoral 2013 with contract number: 020A/UN33.8/KEP/KU/2013. 


\section{REFERENCES}

[1] Mitchell. J.K, Fundamentals of Soil Behavior, 2nd Ed. (John Wiley \& Sons, Inc, 1992).

[2] Van Olphen. H, 1977, Clay Colloid Chemistry, Second Edition, (John Wiley \& Sons, United State of America, 1977).

[3] Low. P.F, Fundamental Mechanisms Involved in Expansion of Clays as Particularly Related to Clay Mineralogy, Proceedings of Workshop on Expansive Clays and Shales in Highway Design and Construction, 1973, Vol.I.

[4] Sparks, Donald L., 2003, Environmental Soil Chemistry, (Academic Press, Elsevier Science, USA, Hardback, 2003), 352 pp., ISBN 0-12-656446-9, Author: Smernik R.1.

[5] Gray. D.H, Schlocker. J, Electrochemical Alteration of Clay Soils, Clays and Clay Minerals, (Pergamon Press, 1969), Vol. 17, pp. 309-322.

[6] Panjaitan. Nahesson Hotmarama, Rifa'i. Ahmad, Adi. Agus Darmawan, Sumardi. P, The Phenomenon of Electromigration During Electrokinetics Process On Expansive Clay Soil, International Journal of Civil \& Environmental Engineering IJCEE-IJENS, 2011, Vol:12 No:04.

[7] Panjaitan. Nahesson Hotmarama, Rifa'i. Ahmad, Adi. Agus Darmawan, Sumardi. P, Experimental Study of Cation Exchange on Expansive Clay with Electrokinetics Process, International Journal of Civil \& Environmental Engineering IJCEE-IJENS, 2013, Vol:13 No:02.

[8] Chen, F. H. Foundations on Expansive Soils, 1st Ed, Vol. XII. (New York: Elsevier Scientific Publishing Company, 1975).

[9] Holtz, W., \& Gibbs, H. Engineering Properties of Expansive Clays. Proceeding ASCE., 1956, Vol.121, (pp. 641-677). 